\title{
PRAKTIK INTERNASIONALISASI MEDIA BERITASATU MEDIA HOLDINGS
}

\author{
Oleh: \\ ANIS ENDANG SM \\ Dosen Prodi Ilmu Komunikasi Fakultas Ilmu-Ilmu Sosial UNIVED Bengkulu
}

\begin{abstract}
This study aimed to determine the practice of internationalization carried out by BeritaSatu Media Holdings in supporting global economic interests of Lippo Group Company. Internationalization is an implication of media industrialization which the media company owner sought to reduce the spatial distance to obtain greater profits. Theory of Political Economy Media used to see how media content represents the interests of certain political economy, especially from media owners. To view the practice of internationalization, the concept of spatialization was used. The analysis showed that the practice of internationalization was done by BeritaSatu Media Holdings visible from nine of thirteen brand-owned media were in English, the media focused on business economics and finance or the life of the upper class, BeritaSatu Media Holdings' media distribution limited in cosmopolitan areas, some media published in Indonesia (The Straits Times, ThePeak) had editions in other countries, such as Malaysia, Singapore, and Hong Kong. Of this trend was seen that the reader of BeritaSatu Media Holdings was segmented to the expatriate community and executives. The expatriate community and executives were capital market investors and financial markets, or the part of policy makers in the field of economy both in the private and public sectors who have the power or role for the current financial turnaround either within the scope of national, regional, and multinational.
\end{abstract}

Keywords: Media, Spatialization, Internationalization, BeritaSatu Media Holdings

\section{PENDAHULUAN}

Manusia adalah makhluk yang memiliki sifat dasar rasa ingin tahu (curiosity) dan kebutuhan untuk eksistensi dan aktualisasi diri. Dua kebutuhan ini mendorong manusia untuk berkomunikasi melalui berbagai media, yang mana media ini terus berubah sesuai perkembangan peradaban. Sebelum ditemukannya tulisan, manusia memenuhi kebutuhan informasi dengan bertanya kepada oranglain.Lalu pada masa kekuasan Caesar di Roma, mereka memiliki media yang disebut acta diurna,yaitu menuliskan hasil pertemuan senat pada sebuah batu tulis yang ditempel di dinding (Baran, 2012: 130). Penemuan mesin cetak oleh Guttenberg pada tahun 1450lalu memungkinkan komunikasiterjadi dalam wilayah yang semakin luas melalui terbitnya buku dan majalah secara massal. Peradaban berikutnya ditandai dengan ditemukannya teknologi penyiaran radio pada tahun 1901 dan televisi pada tahun 1920an. Lalupada erasekarang, telah lahir media terhubung (online media) atau internet yang berimplikasi pada alternatif baru dalam cara mendapatkan informasi sekaligus melakukan kegiatan komunikasi.Golding \& Murdock (1997: 255) menekankan fenomena perkembangan komunikasi ini sebagai transformasi dari fenomena sosial tunggal yang tidak kompleks menuju fenomena industri baru yang sangat maju, yang membawa implikasi luas dan beragam.

Berkaitan dengan perkembangan teknologi ini, Noor (2010: 84-85) mengatakan bahwa secara tradisional, perusahaan media beroperasi pada pasar yang 
sesuai dengan konten dan potensi iklannya. Perubahan teknologi yang cepat dan pesat lantas memudahkan pemain baru untuk memasuki bisnis media. Akibatnya, persaingan menjadi semakin ketat,sehingga untuk menjaga eksistensinya di pasar, masing-masing perusahaan media berusaha untuk melakukan ekspansi pasar.Globalisasi dan konvergensi teknologi yang terjadi sekarang ini juga membuka peluang bagi media untuk menyusun konten media ke dalam berbagai format yang berbeda, yaitu cetak, audio,audio-visual maupun online. Hal ini tentu saja mendorong bisnis media untuk beraliansi atau melakukan merger dan akuisisi dengan menjadi bagian dari konglomerasi dalam bentuk lintas kepemilikan (cross-media ownership) untuk memperluas pangsa pasar.

Dalam konteks Indonesia,industri media sudah berkembang sejak akhir tahun 1980an sebagai dampak dari arus liberalisasi ekonomi global yang terjadi di berbagai bidang, sehingga mau tak mau pemerintah melakukan deregulasi ekonomi dengan mengganti state regulation menjadi market regulation(Sudibyo, 2004: 13-14). Era Reformasi lalu menjadi titik melesatnya perkembangan bisnis media, fenomena ini dijelaskan Nugroho dkk sebagai berikut:

'Industri media di Indonesia telah mengalami pasang surut, dari menjadi alat untuk revolusi kemerdekaan di masa awal Republik ini berdiri (1945-1955), menjadi pers partisan selama periode 1965-1980, dan kemudian menjadi industri yang menjanjikan pada akhir tahun 1980an. Pada saat itu, para politisi dan pejabat pemerintah mulai terlibat dalam bisnis media, dan ijin hanya diberikan kepada mereka yang mempunyai hubungan dekat dengan Presiden Soeharto. Situasi lalu berubah sejak era Reformasi.Ijin untuk mendirikan perusahaan mediakhususnya media cetak-dapat diperoleh dengan lebih mudah.Implikasinya, jaringan pers meluas dengan sangat cepat di seluruh negeri (seringkali melalui diversifikasi dari produk pers) sehingga konglomerat media baru seperti Grup Kompas-Gramedia dan Grup Grafiti Pers pun muncul (Nugroho, Putri, Laksmi, 2012: 37)

Dikatakan Golding \& Murdock (1997: 255), terdapat 2 konsekuensi dari industrialisasi komunikasi sebagai hasil dari meningkatnya skala investasi modal, yaitu: (1) jumlah orang yang menggunakan media harus meningkat seiring dengan meningkatnya biaya proses produksi produk media, dan (2) kontrol finansial dan perlengkapan yang dibutuhkan dalam memproduksi produk media cenderung dipegang oleh perusahaan-perusahaan besar, karena mereka memilikimodal besar yang dibutuhkan dalam industri ini. Implikasinya, berbagai cara dilakukan pemilik modal agar keuntungan yang diperoleh medianya lebih besar dibandingkan dengan ongkos produksi yang dikeluarkan, termasukdengan mengatasi masalah ruang dan waktu sehingga produk medianya dapat dijangkau oleh lebih besar khalayak dalam waktu lebih singkat. Proses untuk mengatasi rintangan ruang dan waktu dalam kehidupan sosial ini disebut Henry Lafebvre(dalam Mosco, 2009: 157) sebagai spasialisasi.Dalam bukunya, The Political Economy of Communication,Mosco mengutip pemikiran Karl Marx dalam buku The Grundrisse (1973) yang dekat dengan konsep spasialisasi, yaitu kecenderungan kapitalisme untuk "memusnahkan ruang dengan waktu", yang mengacu pada pertumbuhan kekuatan kapitalisme untuk menggunakan dan memperbaiki sarana transportasi dan komunikasi, serta mempersingkat waktu yang dibutuhkan untuk memindahkan barang, orang, dan pesan, sehingga mengurangi pentingnya jarak spasial sebagai sebuah kendala dalam perluasan modal karena dalam logika kapitalisme,kekayaan yang terakumulasi darisistem produksi, distribusi, dan 
pertukaran ini akan diinvestasikan kembali oleh pemilik pribadi untuk memperoleh keuntungan yang lebih besar.

Konsekuensi dari proses ini adalah konglomerasi, yang mengarah pada oligopoli dan pemusatan (konsentrasi) kepemilikan media. Di Indonesia sendiri, hasil penelitianNugroho dkk (2012) mencatat adanya 12 kelompok media besar yang mengendalikan hampir semua kanal media di Indonesia, termasuk didalamnya media penyiaran, media cetak dan media online. Mereka adalah:MNC Group(memiliki 3 kanal televisi free-to-air, 20 jaringan televisi lokal dan 22 jaringan radio dibawah anak perusahaanSindo Radio), Kelompok Kompas Gramedia(memiliki KompasTV, 12 penyiaran radio di bawah anak perusahaan Radio Sonora, dan 89 perusahaan media cetak), Elang Mahkota Teknologi, Visi Media Asia(memiliki 2 stasiun televisi dan media online vivanews.com), Grup Jawa Pos(memiliki 171 perusahaan media cetak, termasuk Radar Grup), Mahaka Media, CT Group, Beritasatu Media Holdingss(di bawah Grup Lippo, telah mendirikan Internet Protocol Television BeritaSatuTV, kanal media online beritasatu.com dan sejumlah surat kabar dan majalah), Grup Media, MRA Media, Femina Group dan Tempo Inti Media.

Terpusatnya kepemilikan perusahaan media oleh kelompok perusahaan besar dapat terjadi melalui beberapa cara, yaitu: integrasi, diversifikasi, dan internasionalisasi (Golding \& Murdock (1997: 11-21).Integrasi dibedakan Golding \& Murdock menjadi 2, yaitu: integrasi vertikal yang terjadi ketika kelompok bisnis melakukan ekspansi terhadap tahapan produksi yang berbeda, dan integrasi horizontal yang terjadi ketika satu kelompok bisnis memperoleh unit tambahan dalam tingkatan produksi yang sama. Sedangkan diversifikasi terjadi ketika satu perusahaan melakukan ekspansi ke bidang usaha yang lain. Dan internasionalisasi terjadi ketika perusahaan-perusahaan domestik membuka diri terhadap arus investasi asing, melakukan kegiatan eksport dan berbagi kepemilikan saham dengan perusahaan asing.Dikatakan Arestis \& Paliginis (dalam Toporowski, 2002: 154),globalisasi meningkatkan saling bergantungan ekonomi sebagai hasil dari peningkatan perdagangan dan arus modal internasional.

Salah satu perusahaan media di Indonesia yang melakukan praktik internasionalisasi adalah Beritasatu Media Holdings yang merupakan anak perusahaan raksasa Lippo Group.Awalnya, Lippo Group merupakan perusahaanyang bergerak di bidang perbankan dan didirikan oleh Mochtar Riady, lalu kepemimpinan Lippo Group dilanjutkan oleh anaknya, yaitu James Riady. Dalam situs Knowledge@Wharton, dimuat hasil wawancaraJames Riady, CEO Lippo Group, tentang geliat usahanya (terutama di bidang properti dan perbankan) di kawasan Asia Tenggara yang telah meluas hingga China, Hongkong;Cook Island, Amerika Serikat, dan Australia. Tidak hanya itu, Lippo Group juga berencana untuk menginvestasikan dana US\$10 juta di kawasan Asia Pasifik.Selain bergerak di bidang properti dan perbankan, perusahaan ini juga bergerak di bidang telekomunikasi, retail, perawatan kesehatan, dan merupakan pemilik Universitas Pelita Harapan. Dalam laman berita suarapengusaha.com edisi 25 Januari 2013, disebutkan bahwa Lippo Group bekerjasama denganCaesars Entertaiment Corp berencana membangun kompleks kasino di Incheon, Korea Selatan. Tahap pertama dari proyek itu membutuhkan investasi sekitar US\$ 500 juta atau setara Rp 4,88 triliun.Dalam laporan Lippo ke bursa Hong Kong, perusahaan milik James Riady iniakan menjadi pemegang saham minoritas dengan menguasai 20\% saham. Sementara Caesarsakan memiliki 40\% saham, dan mitra lainnya 40\%.

Disebutkan dalam laman tempo.co.id(http://tempo.co.id/ang/pro/1996/ 
james_tjahaja_riady.html) perusahaanJames Riady mulai bergerak di bidang media dengan benderaGlobe Media Group.Globe Media Group menerbitkan majalah Investor pada tahun 1998. Lalu pada tahun 2002Globe Media Group membeli saham Investor Indonesia, surat kabar yang berkonsentrasi pada kegiatan pasarmodal yang dimiliki oleh Tito Sulistio.SetelahGrup Lippo masuk, nama "Investor Indonesia" diubah menjadi “Investor DailyIndonesia”. Pada tahun 2006, Grup Lippo membeli saham Suara Pembaruan.Setelah pada tahun 2011 membeli BeritaSatu.com, namadagang Globe Media Grouplalu diganti menjadi BeritaSatu MediaHoldings hingga sekarang.Selain beberapa media yang disebutkan di atas, BeritaSatu Media Holdings juga memiliki beberapa media lain, diantaranya the Strait Times yang berbasis di Singapura, Majalah Investor, Globe Asia, the Peak, Campus Asia, Jakarta Globe, Kemang Buzz, Student Globe, Campus Life, Campus Asia, dan BeritaSatu

(dalamwww.beritasatumediaholdings.com).

Menariknya, media-media yang diterbitkan oleh BeritaSatu Media Holdings merupakan media bisnis yang ditujukan untuk kalangan pengambil kebijakan dan kalangan menengah ke atas dengan daerah sirkulasi kota-kota metropolitan. Selain itu, sembilan dari tiga belas media yang dimiliki perusahaan ini berbahasa Inggris dan berbasis atau diterbitkan dalam versi beberapa negara lain, seperti Malaysia, Singapuradan Hongkong. Dari uraian di atas, penulis tertarik untuk mengkaji praktik internasionalisasi media-media di bawah perusahaan BeritaSatu Media Holdings untuk mendukung kepentingan ekonomi global perusahaan Lippo Group yang terus melakukan perluasan area bisnis.

\section{KONSEP TENTANG EKONOMI POLITIK MEDIA}

Keterikatan antara kepentingan ekonomi dan politikmenjadikan komunikasi sebagai ranah yang rentan terhadap pengaruhkeduanya. Sebagai entitas yang dikonstruksi oleh media, apa yang disebutsebagai komunikasi sering merepresentasikan kepentingan ekonomisekaligus politik tertentu, terutama dari pemilik media. Vincent Mosco dalam bukunya "The PoliticalEconomy of Communication" mendefinisikan ekonomi politikdalam arti sempit sebagai: "the study of social relations, particularly the power relations, that mutuallyconstitute the production, distribution, and consumption of resources" (2009: 24). Dari definisi ini, terlihat bahwa ekonomi politik merupakan studi mengenai relasi sosial, khususnya yangmenyangkut relasi kekuasaan, baik dalam produksi, distribusi dan konsumsisumber daya dalam ekonomi politik komunikasi. Sumber daya (dalam konteksmedia) dapat berupa televisi, koran, majalah, buku, kaset, film, dsb. Dalam menjelaskanrelasi ini, perlu dipahami konsep tentang sejauh mana media mengambil posisidalam kepentingan dan ideologi, dalam setting kepemilikan (ekonomi) dansetting kekuasaan (politik). Halim (2013: 37) mengutip definisi ekonomi politik dari Eatwell, Milgate, dan Newsman (1987) bahwa ekonomi politik merupakan ilmu kekayaan yang berhubungan dengan usaha manusia guna mendapatkan ebutuhan dan memuaskan keinginannya. Mosco lantas mendefinisikan ekonomi politik secara lebih luas, yaitu 'the study of control and survival in social life", atau ilmu yang mempelajari tentang kontrol dan kebertahanan dalam kehidupan sosial. Secara etimologi, dijelaskan oleh Mosco, bahwa istilah ekonomi berakar pada Yunani klasik:Oikos, yang berarti rumah tangga, dan Nomos berarti ilmu. Politik juga berasal dari istilah Yunani yang berangkat dari unit dasar organisasi politik klasik. Awal mulanya, ekonomi politik berasal dari pengelolaan rumah tangga dan politik. Steuart membuat hubungan dengan mengemukakan bahwa 
ekonomi ada di dalam rumah tangga dan politik ada di dalam negara.

Vincent Mosco menyebutkan tiga konsep penting dalam kajian ekonomi politik media, yaitu: komodifikasi, spasialisasi danstrukturasi. Komodifikasi berhubungan dengan proses transformasibarang dan jasa, dari yang bernilai guna menjadi suatu komoditas yang bernilai tukar (Mosco, 2009: 127). Halim (2013: 46) mengatakan bahwa komodifikasi menghilangkan produk dari konteks sosial yang lebih bermakna menjadi sesuatu yang lebih bermanfaat dalam segi bisnis dan ideologi nilai "pasar bebas". Dalam hal ini, siapa saja yang memulaikapital dengan mendeskripsikan sebuah komoditi maka ia akanmemperoleh keuntungan sangat besar. Dalam lingkup institusi ataulembaga media, para pekerja media dilibatkan untuk memproduksi danmendistribusikannya ke konsumen yang beragam. Konsumen dalam hal inibisa khalayak pembaca media cetak, penonton televisi, maupun pendengar radio. Sedangkan spasialisasi didefinisikan Mosco (2009: 128)sebagai "the process of overcoming theconstraints of space and time in social life, yang diistilahkan Marx dengan "annihilate space with time".

Strukturasi dijelaskan Mosco (2009: 185) sebagai "a process by which structures are constituted out of human agency, even as they provide the 'very' medium of that constitution". Di sini terlihat bahwa strukturasi merupakan proses dimana struktur sosial salingditegakkan oleh para agen sosial, dan masing-masing bagian daristruktur mampu bertindak melayani bagian yang lain. Strukturasi menjelaskantentang relasi ide antar agen masyarakat, proses sosial dan praktik social yang hasil akhirnya berupa serangkaian hubungan sosial dan proseskekuasaan yang diorganisasikan di antara kelas, gender, ras dan gerakan sosial yangmasing-masing berhubungan satu sama lain.

\section{KONSEP TENTANG SPASIALISASI}

Mosco (2009: 128) mendefinisikan spasialisasi sebagai "the process of overcoming theconstraints of space and time in social life”. Dalam bukunya Mosco juga mengutip definisi spasialisasi menurut Henri Levebfre, yaitu"the institutionalextension of corporate power in the communication industry". Dari dua definisi ini terlihat bahwa spasialisasi berkaitan dengan sejauh mana media mampu menyajikanproduknya di depan khalayak dalam batasan ruang dan waktu. Selanjutnya Levebfre juga menyebutkan bahwa ada beberapa level dari ruang, dimulai dari ruang yang paling abstrak dan kasat mata,ruang alamiah (ruang absolut) menuju ruangan yang lebih kompleks yangmaknanya diproduksi secara sosial (sosial space). Ruang sosial ini adalah produk sosial, yaitu ruang yang diproduksi sebagai cara tertentuyang menjadi alat berpikir dan bertindak. Lefebvre berpendapat bahwa produksi sosial atas ruang adalah dasar bagireproduksi masyarakat sebagai akibat dari kapitalisme.

Selain dalam bentuk ruang, Mosco mengatakan bahwa spasialisasi dapat terjadi dalam bentuk perluasan lembaga (institutional extension). Bentuk perluasan dalam hal ini dapat terjadi dalam ukuran lembaga media yang diukur dari aset-aset yang dimiliki, pendapatan, keuntungan, jumlah pekerja atau pegawai, dan nilai saham mereka di pasar finansial. Kajian ekonomi politik memberikan penekanan bentukbentuk pengkonsentrasian perusahaan, atau cara-cara yang ditempuh perusahaan media untuk mendominasi pasar. Alasan utama studi ekonomi politik memberikan penekanan pada hal ini adalah untuk memahami bagaimana kekuasaan dalam industri komunikasi yang terkonsentrasi memiliki dampak yang signifikan bagi masyarakat. Terkonsentrasinya kepemilikan akan membuat institusi pemilik media dapat melakukan kontrol yang lebih baik dalam proses produksi, distribusi dan pertukaran 
komunikasi, selain juga akan membatasi kompetisi karena berkurangnya keragaman informasi dan hiburan yang tersedia di masyarakat.

Menurut Mosco (2009: 159), terkonsentrasinya kepemilikan media dapat terjadi melalui dua cara, yaitu integrasi vertikal (vertical integration) dan integrasi horizontal (horizontal integration). Integrasi vertikal menjelaskan tentang proses integrasi antara indukperusahaan dan anak perusahaannya yang dilakukan dalam satu garis bisnisuntuk memperoleh sinergi, terutama untuk memperoleh kontrol dalamproduksi media (Mosco, 1996:175176). Sedangkan integrasi horizontal terjadi ketika suatu perusahaan dalam satu baris media membeli suatu kepentingan utama dalam operasi media lain sehingga akan mengarah pada bentuk konglomerasi dan monopoli atau oligopoli. Berbeda dengan Mosco, Golding \& Murdock(1997: 11-21) berpendapat bahwa terkonsentrasinya kepemilikan dapat dilakukan melalui3 cara: integrasi (horizontal dan atau vertikal), diversifikasi, dan internasionalisasi.

\section{- Integrasi}

Integrasi dibedakan Golding \& Murdock menjadi 2, yaitu: integrasi horizontal yang terjadi ketika kelompok bisnis melakukan ekspansi terhadap tahapan produksi dalam level atau tingakatan yang sama. Integrasi horizontal memungkinkan perusahaanperusahaan untuk melakukan konsolidasi dan memperluas kendali mereka dalam suatu sektor produksi media tertentu dan memaksimalkan skala ekonomi serta pembagian sumberdaya. Dicontohkan Golding \& Murdock, integrasi horizontal yang pernah terjadi adalah akuisisi dengan cara take-overyang dilakukan Penguin Books(perusahaan pemroduksi sampul terbesar di dunia) oleh Pearson Longmans, salah satu perusahaan penerbitan terbesar di Inggris. Contoh lain ditunjukkan oleh akuisisi 2 surat kabar besar "berkualitas", yaitu Timesdan Sunday Times oleh Thomson
Organizationyang waktu itu telah menjadi perusahaan surat kabar terbaik dan menguasai 90 surat kabar di Amerika Serikat dan Kanada, juga 50 surat kabar provinsial dan lokal di Inggris.

Sedangkan Integrasi vertikal terjadi ketika satu kelompok bisnis memperoleh unit tambahan dalam tingkatan produksi di level yang berbeda. Integrasi ini terjadi ketika sebuah perusahaan dalam satu tahapan produksi tertarik untuk memperluas operasi produksi-produksi yang lain, seperti penyediaan bahan mentah, penyediaan modal perlengkapan, serta organisasi distribusi dan penjual eceran. Pertimbangan yang digunakan dalam logika integrasi vertikal ini adalah untuk mengurangi kemungkinan terjadinya fluktuasi dalam persediaan dan biaya bahan-bahan dan pelayanan-pelayanan penting. Pada akhirnya praktik ini memungkinkan perusahaan untuk mengatur dan merasionalisasi lebih banyak proses produksi, sehingga juga dapat memperbesr kendali perusahaan atas pasar.Contoh dari integrasi ini adalah merger antara perusahaan penerbitan IPC dengan Reed Group Limited, perusahaan internasional yang bergerak dalam bidang kayu, bubur kertas (pulp), kertas dan kertas koran.Dikatakan Golding \& Murdock kalau kedua praktik integrasi ini dapat dilakukan melalui merger (penggabungan) dan take-over(akuisisi atau memperoleh kendali melalui pembelian saham).

- Diversifikasi

Diversifikasi terjadi ketika satu perusahaan melakukan ekspansi ke bidang usaha yang lain. Diversifikasi memungkinkan perusahaan untuk mengurangi efek resesi dalam sektor tertentu. Selain mengurangi efek resesi, diversifikasi juga memungkinkan perusahaan untuk mengesahkan keberhasilan komoditas yang dihasilkan perusahaan dengan menghasilkan sejumlah produk dalam sektor lain. Contoh diversifikasi adalah merger antara perusahaan telekomunikasi dengan televisi, 
dimana layanan audio-visual dan telepon didistribusikan bersama-sama di seluruh infrastruktur yang dimiliki (Noor, 2010: 87).

- Internasionalisasi

Dan internasionalisasi terjadi ketika perusahaan-perusahaan domestik membuka diri terhadap arus investasi asing, melakukan kegiatan eksport dan berbagi kepemilikan saham dengan perusahaan asing. Dikatakan Arestis \& Paliginis (dalam Toporowski, 2002: 154), globalisasi meningkatkan saling bergantungan ekonomi sebagai hasil dari peningkatan perdagangan dan arus modal internasional. Keterlibatan perusahaan bisnis media dalam ekspansi kerajaan bisnis sangat penting, baik sebagai media perpanjangan tangan dari kerajaaan bisnis tersebut,maupun sebagai sumber pendapatan bagi media (Golding \& Murdock, 1997: 20).

\section{Profil BeritaSatu Media Holdings dan Lippo Group}

Beritasatu Media Holdings atau lebih dikenal sebagai BeritaSatu Media, sebelumnya bernama Globe Media Group.Pada bulan Februari 2011, Globe Media Groupmembeli BeritaSatu.com, situs berita yang beroperasi sejak Mei 2010. Pembelian situs ini semakin menambah panjang deretan media yang bernaung di bawah bendera Globe Media Group. Nama "BeritaSatu" kemudian menjadi merek dagang baru untuk kelompok media ini.Pada tanggal 3 September 2011, BeritaSatu Media meluncurkan BeritaSatu TV.Sebagaisebuah grup media, BeritaSatu Media Holdings memiliki banyak brand, baik media cetak berbahasa Indonesia. Dalam situsresmi BeritaSatu Media Holdings (www.beritasatumedia.com), disebutkan media-media yang dimiliki yakni Suara Pembaruan dan InvestorDaily, maupun media cetak berbahasa Inggris, yaitu Jakarta Globe dan Strait TimesIndonesia, surat kabar hasil kerja sama dengan Singapore Press. Selain memiliki surat kabar dan televisi, Beritasatu Media Holdings juga memilikimajalah bisnis terkemuka di Indonesia, yaitu majalah Investor dalam bahasa Indonesia dan Globe Asia,Student Globe,The Peak, Campus Asia, Campus Life,dan KemangBuzz dalam bahasaInggris.Beritasatu Media Holdings merupakan salah satu grup media di bawah Lippo Group.Berikut merupakan bagan kerajaan perusahaan Lippo Group:

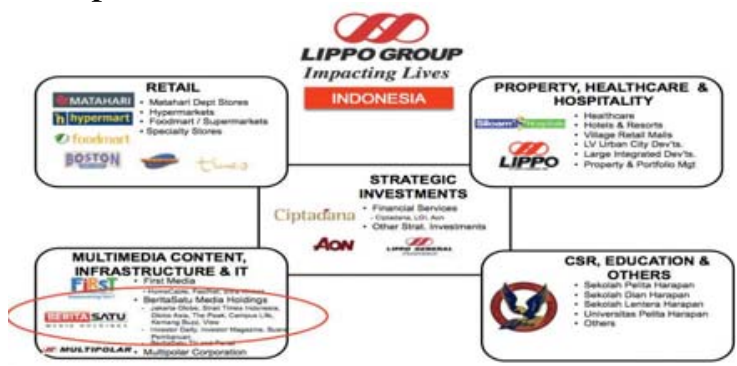

\section{Media-media di bawah perusahaan BeritaSatu Media Holdings}

- Situs online: Beritasatu.com

Dalam situs resmi Beritasatu.com (http://beritasatumedia.com/content/aboutus/) disebutkan bahwa Beritasatu.com adalah situs berita dan opini yang memiliki keunggulan pada kecepatan, ketepatan, kelengkapan, pemilihan isu yang tepat, dan penyajian yang memperhatikan hukum positif dan asas kepatutan.Jurnalisme yang diterapkan adalah Jurnalisme Positif, yakni aktivitas jurnalistik yang dijalankan dengan baik dan benar sesuai kaidah jurnalistik dan asas kemanusiaan agar berita dan opini yang disajikan tidak saja objektif dan bermakna, melainkan juga mampu membangkitkan optimisme dan perilaku positif para pembaca.

- Surat kabar

BeritaSatu Media Holdings memiliki empat brand surat kabar, yaitu: The Jakarta Globe, Investor Daily, Suara Pembaruan dan The Street Times. Dalam situs resminya, http://www.thejakartaglobe.com/about-us/, disebutkan bahwa The Jakarta Globeadalah surat kabar harian berbahasa Inggris di Indonesia yang diluncurkan padaNovember 2008. Surat kabar ini rata-rata mencetak 48 
halamanper hari, dan terbit dari Senin sampai Sabtu. Surat kabar ini memiliki 3 bagian: bagian A berisi berbagai berita umum, termasuk liputan berita metropolitan dannasional serta berita internasional; bagian B merupakan bisnis Indonesia dan dunia olahraga; bagian Cmerupakan fitur yang luas, meliputi gaya hidup serta hiburan, daftar layananpembaca dan tekai-teki atau kartun. Koran ini terutama dipasarkan di kosmopolitan. Sedangkan Investor Daily, disebutkan dalam situs Wikipedia, merupakan surat kabar berbahasa Indonesia yang didirikan pada 26 Juni 2001 dan merupakan surat kabar yang berkonsentrasi pada kegiatan pasarmodal. Investor Daily dulunya merupakan surat kabar siang dengan nama Investor Indonesia. Pada tahun 2002 Group Lippo masuk sebagai pemegang saham di Investor Group dan saat ini telah menguasai secara penuh saham Investor Group. SetelahGrup Lippo masuk, nama "Investor Indonesia" diubah menjadi "Investor DailyIndonesia”. Selain berisi bahasan ekonomi dan bisnis, koranini jugamenambahkan beberapa rubrik lain, seperti olahraga, gaya hidup dan kosmopolitan. Sirkulasi Indonesia Daily mencakup kota-kota bisnis di Indonesia dengan targetpembaca pelaku bisnis dan pengambil keputusan.Selain dalam bentuk cetak, Investor Daily telah hadir dalam bentuk online dengan alamat domain www.investor.co.id. Portal ID ini memiliki target pembaca kalangan wirausahawan, investor pasar modal dan pasar keuangan, serta pengambil kebijakan di korporasi dan pemerintahan. Meski demikian Portal ID pun layak dibaca oleh pembaca umum karena juga meng-cover berita nasional, internasional, olahraga hingga gaya hidup.

Sedangkan Suara Pembaruan merupakan media cetak yang pertama kali terbit pada 27 April 1961 dengan namaSinar Harapan dan dikelola oleh PT. Sinar Kasih. Kemudian di tahun 1986, harian umum ini dicabut izin terbitnya (dibreidel) oleh pemerintah orde baru. Lalu pada4 Februari 1987 pengelola diizinkan kembali menerbitkan koran dengannama baru yaitu Suara Pembaruan dengan nama penerbit baru, yakni PT. MediaInteraksi Utama. Berlanjut hingga 2006, Suara Pembaruan bermitradengan Globe Media Group yang sekarang telah berubah nama menjadi Beritasatu Media Holdings.The Strait Times adalah koranberbahasa Inggris yang berbasis di Singapura dan dimiliki oleh Singapore Press Holdings. Koran ini merupakan media cetakyang dipublikasi di Indonesia melalui jalinan kerja sama dengan Singapore PressHoldings dibawah pengaturan Beritasatu Media Holdings(dalam Hernando, 2012: p39).

- Majalah

Diuraikan dalam Dewi, 2012: p,30-32) BeritaSatuMedia Holdings memiliki tujuh brand majalah, yaitu: Majalah Investor(merupakanmajalah berbasis bisnis dengan pasar utama Indonesia yang jugaberisi publikasimengenai Industry Awards dalam berbagai kategori seperti "Best Bank", "BestInsurance", "Best Listed Companies”, "Best Syariah”, dll); Globe Asia (majalah bisnis berbahasa Inggris terkemuka di Indonesia dan merupakan satu kategori dengan majalah Forbes); The Peak (merupakan majalah berbahasa Inggris edisi Indonesia atas lisensi dari SPH Magazine PTELTD., Singapore, juga diterbitkan edisi Sigapura, Hongkong dan Malaysia yangmemuat profil tokoh, hotel, fashion, feature, restoran, mobil, kuliner, dll. Beberapanama rubriknya, antara lain, The Brief; Pursuit; Passion); Campus Asia (merupakan majalah berbasis pendidikan dan dunia kampus yang ditulis dalam bahasa Inggris); Student Globe (adalah media cetak mingguan berbasis bahasa Inggris yang dibuat untukpelajar SMP dan SMA yangdibaca oleh lebih dari 20.000 siswa di lebih dari 120 sekolah mitra); Kemang Buzz (adalah majalah yang berisi ulasan mengenai 
gaya hidup dalambahasa Inggris yang bertujuan untuk memberdayakan masyarakat dan bisnis lokal di lingkungan sejahtera);Campus Life (majalah berbahasa Inggris untuk edisi mingguan dan berbahasa Indonesia untuk edisi bulanan yang dikhususkan sebagai penghubung untuk semua mahasiswa yang perlumenjalani hidup dengan penuh (live life to the fullest), berisiartikel-artikel menarik seputar pelajaran,mode, kesehatan, cinta, karir, dan kehidupan mahasiswa secara).

- Televisi: BeritaSatu TV

BeritaSatu Tv yang sebelumnya bernama Qtv dan QChannel, merupakan salurankhusus untuk membahas soal-soal keuangan. Saluran ini hanya dapat disaksikan melalui satelit dan kabel. Pemilik yang sekaligus pendirinya adalahPeter F. Gontha. Televisi ini telah menggunakan teknologi IPTV, atau Internet Protocol Television, yaitu layanan televisi dengan jaringan Internet yang menggunakan arsitektur jaringan dan metode suite protokol Internet melalui paket-switched Jaringan Infrastruktur, misalnya, Internet dan jaringan Internet akses broadband, bukan menggunakan frekuensi radio, sinyal satelit, dan televisi kabel(dalam Dewi, 2012: p.32).

\section{Lima Sektor Utama Bisnis Lippo Group}

Beritasatu Media Holdings merupakan anak perusahaan dari Lippo Group yang didirikan pada tahun 2011. DalamHernando (2012: p. 34) diuraikan bahwa sebelumnya Lippo Group telah memiliki lini bisnis di berbagai bidang, tepatnya sejak tahun 1981 oleh Mochtar Riady yang pada waktu itu masih bernama Tionghoa, LieMo Tie. Mochtar Riady membeli sebagian saham di Bank Perniagaan Indonesia milik Haji Hasyim Ning. Waktu dibeli, aset bank milik keluarga Hasyim telah merosot ke sekitar Rp16,3 miliar. Pada waktu itu, Mochtar tengah menduduki posisi penting di Bank CentralAsia, bank yang didirikan oleh keluarga Liem Sioe Liong. Ia bergabung dengan BCA pada 1975dengan meninggalkan Bank Panin.Walau telah memiliki saham di bank lain, Mochtar baru keluar dari BCA pada akhir 1990 ketika aset bank tersebutsudah di atas Rp5 triliun.Setelah Mochtar bergabung, pada tahun 1987 aset Bank PerniagaanIndonesia melonjak lebih dari 1.500 persen menjadi Rp 257,73 miliar. Hal ini membuatkagum kalangan perbankan nasional. Mochtar dijuluki sebagai The Magic Man of Bank Marketing.Dua tahun kemudian, bank ini melakukan merger dengan Bank Umum Asia.Sejak saat itu lahirlah Lippobank. Ini merupakan cikal bakal Lippo Group.Perusahaan ini lantas mengembangkan diri di usaha properti yang kemudian berkembang di Indonesia. Dengan lebih dari 50 anak perusahaan, aktivitas grup ini merambah dikawasan Asia Pasifik, terutama Hong Kong, Guang Zhou, Fujian dan Shanghai.

DisebutkanHernando (2012: p. 34-36) saat ini setidaknya Lippo Group memiliki 5 area bisnis utama. Pertama, jasa keuangan yang meliputi perbankan, investasi, asuransi, sekuritas,manajemen aset dan reksadana. Jasa keuangan ini adalah core bisnis Lippo. Dalam bisniskeuangan ini, Lippo cukup konservatif, sehingga bank ini selamat dari guncangan krisismoneter, walaupun sempat digoyang isu kalah kliring (1995) dan persoalan rekapitalisasi(1999). Perusahaan sekuritasnya, Lippo Securities, juga memiliki reputasi yang baik. Begitu pula di bidang investasi, yakni Lippo Investment Management, LippoFinance dan Lippo Financial; jasa asuransi dengan perusahaan AIG Lippo (Lippo Insurance) dan Asuransi Lippo ( Lippo General Insurance).Kedua,properti dan urban development. Bisnis yang meliputi pembangunan kotasatelit terpadu, perumahan, kondominium, pusat hiburan dan perbelanjaan, perkantorandan kawasan industri. Lippo tidak hanya membangun perumahan, namunkota yanglengkap dengan 
berbagai infrastruktur, misalnya LippoCikarangdi timur Jakarta dan Bukit Sentuldi selatan Jakarta. Ketiga, pembangunan infrastruktur seperti pembangkit tenaga listrik, produksigas, distribusi, pembangunan jalan raya, pembangunan sarana air bersih, dan prasaranakomunikasi. Keempat, bidang industry, meliputi industri komponen elektronik, komponenotomotif, industri semen, porselen, batu bara dan gas bumi. Lippo Industries,memproduksi komponen elektonik seperti kulkas dan AC sertakomponen otomotif memproduksi kabel persneling.Kelima, bidang jasa-jasa yang meliputi teknologi informasi, bisnis ritel, rekreasi,hiburan, hotel, rumah sakit, dan pendidikan. Lippo Group membangun Rumah Sakit untuk kelas atas di Lippo Karawaci denganmenggandeng Gleneagles Hospital yang berbasis di Singapura. Selain Rumah Sakit, ia juga mendirikan Universitas Pelita Harapan. Universitas inimendapat sorotan karena biayanya menggunakan dolar AS dan dinilai mahal. Dengan visi "To be a prime national educational resource for applying total transformational principles that empower future leaders to transform people in a balanced and integrated manner; to enhance knowledge and technology; to develop good character and attitude and to glorify

God"(dalam http://www.uph.edu/)para pendiri Lippo beranggapan bahwa pendidikan yang disediakan olehSekolah Pelita Harapan adalah yang terbaik.Selain wajib berbahasa Inggris, merekamemperoleh tambahan pendidikan ekstra kurikuler seperti pelajaran musik, berkuda danilmu komputer. Guruguru pun didatangkan dari Amerika.Di bisnis ritel, ketika Grup Lippo membeli lebih dari50 persen saham Matahari Putra Prima, perusahaan ritel terbesaryang dimiliki HariDarmawan pada tahun 1996.Pada 19 Juni 2014, Matahari Department Store telah membuka toko ke-127 yang berlokasi di Lippo Mall Puri (http://www.thejakartaglobe.com/business/m atahari-department-store-opens-127th-storelippo-mall-puri/).

\section{Praktik Internasionalisasi BeritaSatu Media Holdings untuk Mendukung Kepentingan Ekonomi Global Lippo Group}

Dalam bukunya, The Political Economy of the Media volume I, Golding \& Murdock mengatakan bahwa dalam internasionalisasi yang melibatkan investasi asing dan meningkatnya ekspor,keterlibatan dalambisnis media untuk ekspansi kerajaan bisnis adalah sangat penting, baik sebagai media perpanjangan tangan dari kerajaaan bisnis tersebut, maupun sebagai sumber pendapatan (1997: 19-20). Berkaitan dengan perusahaan Beritasatu Media Holdings, berdasarkan pengamatan penulis, praktik internasionalisasi dalam konteks media yang dilakukan terlihat dari:

1. sembilan dari tiga belas brand media yang dimiliki menggunakan bahasa Inggris (untuk kalangan terbatas).

2. media-media di bawah bendera BeritaSatu Media Holdingsmerupakan media yang memfokuskan diri pada bidang ekonomi bisnis dan keuangan, atau kehidupan mapan kalangan kelas atas.

3. selain Suara Pembaruan, distribusi media-media BeritaSatu Media Holdings terbatas di daerah-daerah kosmopolitan.

4. beberapa media yang diterbitkan di Indonesia (The Street Times, The Peak) memiliki edisi di negara lain, seperti Malaysia, Singapura, dan Hongkong.

Dari keempat hal tersebutterlihat bahwa media-media BeritaSatu Media Holdings sangat segmented dan ditujukan untuk kalangan ekspatriat dan eksekutif, termasuk orang-orangterdekat (keluarga) mereka. Kalangan ekspatriat dan eksekutif ini merupakan investor pasar modal dan pasar keuangan, dan atau bagian dari pengambil kebijakan dalam bidangekonomi, baik dari sektor swasta maupun pemerintah 
yang memiliki kuasa atau peran untuk perputaran arus keuangan, baik dalam lingkup nasional, regional, maupun multinasional.

Berkaitan dengan investasi atau kerjasama asing dalam konteks media, dalam Hernando (2012: p. 39) disebutkan bahwa koran Straits Timesyang diterbitkan di Indonesia dibawah pengaturan Beritasatu Media Holdings adalah koran yang berbasis di Singapuradan dimiliki oleh Singapore Press Holdingsyang dipublikasi di Indonesia melalui jalinan kerja sama dengan Singapore PressHoldings. Dengan situs resmi www.straittimes.com,di dalam situs Wikipediadisebutkan bahwa koran ini memiliki koresponden khusus di kota-kota utama di seluruh dunia.Disebutkan pula bahwa The Straits Times adalah satu-satunya koran berbahasa Inggris yang aktif dalam forum Internet di Singapura.Selain menerbitkan The Straits Times, di Singapura perusahaan ini juga menerbitkan Sunday Times, koran berpenjualan tertinggi di negara tersebut dengan sirkulasi mencapai 365,800.The Straits Timesjuga memiliki Media Club, yaitu program yang ditujukan untuk mendorong orang muda membaca dan tertarik pada isu-isu yang sedang berkembang.

Selain The Straits Times, bentuk kerjasama dengan asing dalam menjalankan bisnis media juga terlihat dari The Peakyang diterbitkan di Indonesia (edisi Indonesia) atas lisensi dari SPH (Singapore Press Holdings) Magazine PTELTD., Singapore, yang juga menerbitkan majalah serupa diSingapura, Hongkong dan Malaysia. Dalam situs resminya, http://www.thepeakmagazine.com/id/about disebutkan bahwa dalam setiap edisinya, majalah ini membawa perpaduan informasi eksklusif untuk orang-orang yang berada di 'puncak permainan' mereka.The Peak menyajikan panduan penting untuk perkembangan perusahaan, profesional, lingkungan sosial dan budaya. Majalah ini dikonsumsi oleh asosiasi-asosiasi penting, sepertiThe Singapore Diplomatic Corps, YoungEntrepreneurs Organisation, Young Presidents Organisation dan Ernst \& Young Entrepreneur of the Year Award. Selain itu, beberapa maskapai ternama seperti Singapore Airlines, Air France, Lufthansa and Cathay Pacific menyediakan majalah ini untuk penumpang kelas utama dan kelas bisnis mereka. dalam laman resminya ini, ditampilkan pula profil pembaca the Peak,dimana pembaca majalah ini didominasioleh laki-laki (73\%) berusia 30-49 tahun (67\%) dengan penghasilan rata-rata di atas US\$200,000 pertahun.Pembaca majalah ini berasal dari berbagai latar belakang, tapi hampir semuanya merupakan profesional yang menempati posisi senior di perusahaan.

Geliat ekspansi yang dilakukan Lippo Group secara terus-menerus, baik di dalam maupun luar negeri sering menjadi sorotan media, baik media dalam negeri maupun media asing.Dalam Suara Pembaruan online edisi Selasa, 14 Mei 2013 misalnya, disebutkan bahwa di Padang, Lippo Grup telah melakukan ground breaking proyek senilai Rp 1,3 triliun, berupa kawasan terintegrasi, yaitu: mall, hotel, dan rumah sakit. Selain itu akan dibangun juga Bandara Minangkabau di lahan reklamasi seluas 700 hektare dengan biaya Rp 5-10 triliun. Di Jakarta, Lippo tengah membangun Holland Village senilai Rp 5 triliun. Kelompok ini juga akan membangun 13 mall di seluruh Indonesia dengan biaya investasi US\$ 450 juta hingga 2015. Kemudian dalam laman berita ETCNBC.comedisi 1 Mei 2014, Christine Tan melaporkan ketertarikan pendiri Lippo Group, Mochtar Riady untuk berinvestasi di pasar properti Amerika Serikat. Sebelumnya, Lippo Group yang memegang aset lebih dari \$15 miliar telah membeliTower Bank di Los Angeles setinggi 72 lantai seharga \$368 juta dan meluncurkan investasi keduanya di bidang real-estatedi negara itu. Dalam laman BeritaSatu.com edisi Selasa, 28 Januari 2014 diberitakan 
bahwa Lippo Group akan menjalin kerja sama dengan perusahaan asal Jepang, Mitsui \& Co. di sejumlah bidang antara lain telekomunikasi, teknologi dan multimedia serta perkebunan.Kedua kelompok perusahaan investasi raksasa ini menargetkan akan mengerjakan 20 - 30 proyek kerja sama dengan total investasi berkisar US\$ 4-5 miliar atau sekitar Rp 48,7 -Rp 60,9 triliun.

Berbagai keberhasilan dan kerjasama yang dilakukan Lippo Group ini disebarluaskan dalam berbagai media yang dimiliki. Ketika mengetik "Lippo Group" padasearch boxlaman The Jakarta Globe, terdapat 57 halaman berita dimana masingmasing halaman berisi 10 judul berisi ekspansi usaha atau kesuksessan Lippo Group, seperti: Lippo Kicks Off \$292m St. Moritz in Makassar (edisi 18 Juni 2014), Matahari Department Store Opens 127th Store At Lippo Mall Puri (edisi 19 Juni 2014), Lippo Group Breaks Ground on Shopping Mall in East Nusa Tenggara (edisi 12 Juni 2014), Lippo Group Starts $\$ 51 \mathrm{~m}$ Kupang Mall (edisi 12 Juni 2014), Lippo Karawaci to Commence Rp 200t 'Millennium' Project (edisi 23 Mei 2014), Foreign Investors Rush for Lippo Karawaci Bonds (edisi 7 April 2014), Lippo Cikarang Targets 22\% Profit Rise (edisi 8 Mei 2014), 20 New Hypermarts Due This Year (edisi 9 Mei 2014), Lippo Group's Big TV Looking to Mitsui for Tech Expertise \& Content (edisi 29 April 2013).

Berita-berita dengan tone serupa juga dapat ditemui di laman Investor Daily. Ketika mengetik “Lippo Group” pada search box, dari 180 berita yang muncul semua berkisah tentang kesuksesan Lippo Group. Beberapa berita diantaranya adalah: Lippo Bangun Mall di Kupang Senilai Rp $600 M$ (edisi 12 Juni 2014), Gubernur NTT Minta Lippo Bantu Pengusaha Kecil (edisi 11 Juni 2014), Lippo Karawaci Tbk Raih Anugerah BCI Award 2014 (edisi 11 Juni 2014), Hingga 2020, Lippo Tambah 50 Hotel Aryaduta(edisi 3 Juni 2014), LPKR
Luncurkan

Menara

Perkantoran Lippo Tower Holland Village (edisi 4 Mei 2014), Gubernur Ajak Lippo Bangun Daerah Kepulauan (edisi 25 Februari 2014), Lippo Bangun Superblok Rp 1,8 Triliun di Manado(edisi 20 Februari 2014),RS Siloam-Lippo Group Bantu Layanan Kesehatan Pengungsi Sinabung (edisi 13 Februari 2014), Lippo Beri Bantuan Rp 1 Miliar Bagi Korban Banjir Manado (edisi February 7, 2014).

Sedangkan beberapa berita yang dimuat dalam laman Suara Pembaruan adalah: Lippo Group Bangun Rumah Sakit Internasional dan Sekolah di Kalteng (edisi 6 Juni 2014), Unpatti Sambut Baik Tawaran Beasiswa dari Lippo Group (edisi 19 Mei 2014), Gubernur Maluku dan Wali Kota Ambon Apresiasi Kepedulian Lippo Group (edisi 17 Mei 2014), Lippo Grup Investasikan Rp 600 Miliar Untuk RS Siloam Ambon (edisi 17 Mei 2014), James Riady Tawarkan Beasiswa Anak Maluku (edisi 17 Mei 2014), Hankook Jadikan RI Basis Ekspor Ban (edisi 18 September 2013), Lippo Group Investasi di Minahasa Selatan (edisi 9 Maret 2013), Perkuat Ritel, LPKR Alokasikan US\$ 165 Juta ke Reit (edisi 23 Mei 2011),LPKR Laksanakan Topping Off Menara Apartemen St Moritz (edisi 19 Mei 2011), LPKR Terbitkan Saham Baru Senilai US\$ 112 Juta (edisi 19 Mei 2011).

Jika melihat kecenderungan pemberitaan media-media BeritaSatu Media Holdings beberapa bulan terakhir, terlihat bahwa Lippo Group sedang fokus untuk berinvestasi dan melakukan kegiatankegiatan sosial di Indonesia bagian timur. Dalam laman berita inspirasibangsa.com edisi 15 April 2014, Dr. Anita Maharani (dosen Fakultas Ekonomi dan Bisnis Universitas Paramadina, Jakarta), mengatakan bahwa Kawasan Timur Indonesia (KTI) yang terdiri dari: Kalimantan Barat; Kalimantan Tengah; Kalimantan Selatan; Kalimantan Timur; Nusa Tenggara Barat; Nusa Tenggara Timur; 
Sulawesi Utara; Sulawesi Tengah; Sulawesi Selatan; Sulawesi Tenggara; Gorontalo; Maluku Utara; Maluku; dan Propinsi di Irian Jaya, bisa memberi kontribusi yang tinggi dalam pertumbuhan ekonomi nasional, terutama untuk dalam kegiatan ekspor-impor. Lippo Group sepertinya jeli dalam melihat peluang ini sehingga melakukan banyak investasi. Potensi-potensi yang dimiliki Indonesia Timur dan kegiatan-kegiatan investasi yang dilakukan Lippo Group lantas diberitakan dalam media-media di bawah anak perusahaan BeritaSatu Media Holdings yang dikonsumsi oleh kalangan ekspatriat dan eksekutif yang terdiri dari wirausahawan, investor pasar modal dan pasar keuangan, serta pengambil kebijakan di korporasi dan pemerintahan, baik yang berada di dalam negeri maupun di negara lain. Hal ini tentu saja membawa dampak positif bagi Lippo Group karena dapat mengundang pihak lain, terutama pihak asing untuk ikut menanamkan modal atau melakukan bekerjasama sehingga kerajaan perusahaan Lippo Group dapat terus berkembang.

\section{PENUTUP \\ Kesimpulan}

Berdasarkan pembahasan yang diuraikan di atas, penulis menyimpulkan:

1. Manusia menggunakan media komunikasi dan informasi sesuai dengan perkembangan peradaban dimana manusia tersebut hidup.Pesatnya perkembangan teknologi informasi dan komunikasi, membawa implikasi yang besar dalam dunia media, dimana penyampaian informasi yang dulu dilakukan perseorangan, berubah menjadi suatu industri vital dalam sebuah negara.

2. Globalisasi dan konvergensi membuka peluang bagi media untuk menyusun konten media ke dalam berbagai format yang berbeda, yaitu cetak, audio, audiovisual maupun online. Hal ini mendorong bisnis media untuk beraliansi atau melakukan merger dan akuisisi dengan menjadi bagian dari konglomerasi dalam bentuk lintas kepemilikan (cross-media ownership) untuk memperluas pangsa pasar.

3. Dalam konteks Indonesia, konglomerasi ini terlihat dari berkuasanya 12 kelompok perusahaan besar yang menguasai puluhan media, baik cetak, elektronik, maupun online.

4. Ada 3 cara yang dilakukan perusahaan untuk meluaskan pangsa pasar dan mengamankan bisnisnya, yaitu: Integrasi, Diversifikasi, dan Internasionalisasi.

5. Praktik Internasionalisasi dilakukan BeritaSatu Media Holdings untuk mendukung kepentingan ekonomi global perusahaan raksasa ini.Hal ini terlihat dari: sembilan dari tiga belas brand media yang dimiliki menggunakan bahasa Inggris (untuk kalangan terbatas), mediamedia di bawah bendera BeritaSatu Media Holdings merupakan media yang memfokuskan diri pada bidang ekonomi bisnis dan keuangan, atau kehidupan mapan kalangan kelas atas, selain Suara Pembaruan, distribusi media-media BeritaSatu Media Holdings terbatas di daerah-daerah kosmopolitan, beberapa media yang diterbitkan di Indonesia (The Street Times, The Peak) memiliki edisi di negara lain, seperti Malaysia, Singapura, dan Hongkong.

6. Dari kecenderungan media-medianya, terlihat bahwapembaca BeritaSatu Media Holdings sangat segmented dan ditujukan untuk kalangan ekspatriat dan eksekutif, termasuk orang-orang terdekat (keluarga) mereka. Kalangan ekspatriat dan eksekutif ini merupakan investor pasar modal dan pasar keuangan, dan atau bagian dari pengambil kebijakan dalam bidang ekonomi, baik dari sektor swasta maupun pemerintah yang memiliki kuasa atau peran untuk perputaran arus keuangan, baik dalam lingkup nasional, regional, maupun multinasional. 


\section{Saran}

Pemerintahan perlu membuat regulasi yang jelas dan tegas untuk mengatur kepemilikan media mengingat media memiliki peran yang vital dalam kehidupan sehari-hari masyarakat. Industrialisasi komunikasi berbahaya untuk masyarakat, karena secara ekonomi, mereka hanya menjual produk dan secara politik, menggunakan media untuk kepentingan pemilik dan kelompoknya.

\section{DAFTAR PUSTAKA}

Arestis, Philip \&Eleni Paliginis. (2002). "New Capitalism: Essays in Honor of Sam Aaronovitch (Jan Toporowski, ed)". London: Routledge.

Baran, Stanley J. (2013). "Pengantar Komunikasi Massa: Melek Media \& Budaya (diterjemahkan oleh S. Rouli Manalu)”. Jakarta: Erlangga.

Halim, Syaiful. (2013). "Postkomodifikasi Media: Analisis Media Televisi dengan Teori Kritis dan Cultural Studies". Jakarta: Jalasutra.

Golding, Peter \& Graham Murdock. (1997). "The Political Economy of The Media Volume I". United Kingdom: Edward Elgar Publishing Limited.

Mosco, Vincent. (2009). "The Political Economy of Communication, $2^{\text {nd }}$ Edition”. London: Sage Publication.

Noor, Henry Faizal. (2010). "Ekonomi Media”. Jakarta: Rajawali Pers.

Nugroho, Y., Putri, DA., Laksmi, S. (2012). "Memetakan lansekap industri media kontemporer di indonesia (edisi berbahasa indonesia). Laporan. Bermedia, memberdayakan masyarakat: memahami kebijakan dan tatakelola media di indonesia melalui kacamata hak warga negara". Riset kerjasama antara Center For Innovation Policy And Governance Dan Hivos Kantor Regional Asia Tenggara, didanai Ford Foundation. Jakarta: CIPG dan HIVOS.

Syahputra, Iswandi. (2013). "Rezim Media: Pergulatan Demokrasi, Jurnalisme, Infotainment dalam Industri Televisi”. Jakarta: PT Kompas Gramedia Pustaka Utama

Sudibyo, Agus. (2004). "Ekonomi Politik Media Penyiaran”. Yogyakarta: LKiS

\section{Pustaka online:}

www.beritasatumedia.com

https://knowledge.wharton.upenn.edu/article/ lippo-group-ceo-james-riady-money-andpower-are-a-blessing-and-a-curse/ http://suarapengusaha.com/2013/01/25/lippogroup-perusahaan-milik-james-t-riadybangun-kasino-di-korea-selatan/ http://tempo.co.id/ang/pro/1996/james_tjahaj a_riady.htm

http://www.kompas.com/kompascetak/0101/13/ln/jame03.htm http://beritasatumedia.com/content/aboutus/ http://www.thejakartaglobe.com/about-us/ http://www.investor.co.id/pages/static/aboutu s.php

http://www.suarapembaruan.com/pages/static /aboutus.php

http://www.investor.co.id/pages/majalahinvestor/2014/mar/

http://www.thejakartaglobe.com/pages/globe asia/digital/

http://www.thejakartaglobe.com/pages/globe asia/2014/mar/

http://www.thepeakmagazine.com/id/about http://www.getscoop.com/magazines/campus -asia/febapr-2011

http://www.uph.edu/

http://www.thepeakmagazine.com/id/about http://tempo.co.id/ang/pro/1996/james_tjahaj a_riady.html

http://www.suarapembaruan.com/ekonomida nbisnis/lippo-salim-sinar-mas-mnc-grupusaha-agresif-ekspansi/35445

http://www.cnbc.com/id/101695206 
http://business.bisnis.com/consumer/read/201 30920/116/19003/lippo-group-eyes-on-usreal-estate

http://www.beritasatu.com/ekonomi/163345gandeng-mitsui-lippo-group-investasi-rp-60triliun.html

Hernando, Hansen.(2012). “Analisis Model Proses Komunikasi Event "Eco Walk And Bike 2012” Sebagai Kampanye Public Relations Jakarta Globe". Skripsi. Fakultas Ekonomi Dan Komunikasi Jurusan Komunikasi Pemasaran Universitas Bina Nusantara”http://thesis.binus.ac.id/do c/Bab3/2011-2-00824-MC

Bab3001.pdf
http://www.thejakartaglobe.com/search/Lipp o+group/ http://www.thejakartaglobe.com/search/Lipp o+group/page/3/

http://inspirasibangsa.com/potensi-ekonomikawasan-indonesia-timur/

Dewi, Rizkha Monika. (2012). "Strategi Promosi Beritasatu Media Melalui Event Meet And Greet Manchester United Legend Untuk Meningkatkan Brand Awareness".Skripsi. Jurusan Ilmu Pemasaran. Ilmu Komunikasi Universitas Bina Nusantarahttp://core.ac.uk/download/ pdf/11521550.pdf. 